Institute for Research on Poverty

Discussion Paper no. 1043-94

\title{
Compliance with Child Support Orders in Divorce Cases
}

\author{
Daniel R. Meyer \\ School of Social Work \\ and \\ Institute for Research on Poverty \\ University of Wisconsin-Madison \\ Judi Bartfeld \\ School of Social Work \\ University of Wisconsin-Madison
}

September 1994

This research was supported by a contractual agreement between the Wisconsin Department of Health and Social Services and the Institute for Research on Poverty. This contractual arrangement also supported the collection of the data used in this paper. Any views expressed in this paper are those of the authors and not necessarily those of the DHSS. 


\begin{abstract}
This paper examines compliance with child support orders by divorced fathers in Wisconsin. Compliance increases as the income of the father increases, although it falls in the highest income category. The "burden" of awards does not affect compliance unless more than 30 percent of income is owed. More stringent enforcement systems increase compliance. We find that most divorced fathers who are complying with their orders do not have very low incomes, in contrast to noncomplying fathers in nonmarital cases. This suggests that the best policies to increase compliance among divorced fathers may differ from those for nonmarital fathers.
\end{abstract}




\section{Compliance with Child Support Orders in Divorce Cases}

\section{INTRODUCTION}

The child support system has received an increasing amount of attention as policymakers have focused on the high poverty rates among children in single-parent families, the increase in the number of children who live in these families, and the public cost of supporting children through welfare programs. A frequently cited problem has been (and continues to be) the low rate of compliance with child support obligations. Only half of all mothers with support orders receive the full amount owed, and a quarter receive nothing at all (U.S. Bureau of the Census 1991). Other problems have included low award rates, generally low award amounts relative to noncustodial income, and widely varying awards among parents in similar circumstances.

Since the mid-1970s, lawmakers have responded to these problems with increasingly strict federal legislation intended to increase and standardize the level of awards and to promote compliance with support obligations. The most recent comprehensive legislation is the Family Support Act of 1988. Among other provisions, the FSA mandated that states use a numerical formula to set the level of awards and that child support obligations be routinely withheld from the incomes of noncustodial parents.

In seeking to increase compliance with support orders, legislators have generally focused on enforcement strategies rather than on enhancing the earnings capacity of noncustodial parents. This is consistent with the current prevailing view that noncustodial parents who pay little or no support (the "deadbeat dads" of the press) can afford to pay substantially more than they do. There has been some recent interest, however, in enhancing noncustodial parents' ability to pay, as evidenced by the Parents Fair Share Demonstration, a multistate pilot program that focuses on earnings capacity as well as enforcement. 
In this paper, we examine the determinants of compliance with child support awards. We focus on policy variables of relevance to recent reforms (directly examining the routine withholding of support and indirectly examining the use of income-based support guidelines). We also examine the role of the ability of noncustodial parents to pay support, and the strength of family ties between noncustodial parents and their ex-spouses and children. Our focus here is on divorce cases; we draw on our previous work on compliance in nonmarital child support cases (Bartfeld and Meyer 1994) to highlight similarities and differences between the two groups. In Section II, we review previous literature related to child support compliance; Section III presents data and methods; results are presented in Section IV; and in the last section we discuss conclusions and policy implications.

\section{PREVIOUS LITERATURE}

A number of analyses have examined the determinants of child support compliance. While underlying theoretical models vary, existing research has generally focused on variables related to the noncustodial parent's ability to pay support, his or her willingness to pay (including the strength of family ties between the noncustodial parent and the children, and the economic need of the custodial parent), and the stringency of the enforcement system.

Several researchers have investigated the relationship between compliance and the ability of the noncustodial parent to pay support. Typically, researchers have operationalized "ability to pay" as the income of the noncustodial parent, and have found that higher income is associated with higher compliance (O’Neill 1985; Sonenstein and Calhoun 1990; Danziger and Nichols-Casebolt 1990; Garfinkel and Klawitter 1990; Bartfeld and Meyer 1994). Measures of the noncustodial parent's income have often been problematic, either because they were based on reports by the custodial parent (O’Neill 1985) or because initial income was linked to compliance over a several year period during which income would likely have changed (Danziger and Nichols-Casebolt 1990; Garfinkel and 
Klawitter 1990). Further, researchers have generally not controlled for the share of income owed in support.

In recent work, we addressed these issues in an analysis of compliance in nonmarital cases, controlling for income as well as the percentage of income owed in support (Bartfeld and Meyer 1994). We found that annual income, which we had gathered from state tax returns, was a strong predictor of compliance during the same year; predicted compliance was twenty percentage points higher for a case with income between one and two times the poverty level than for a similar case below poverty. Controlling for income, parents who owed a larger share of their income in support had lower compliance rates.

Variables such as employment status, educational attainment, and marital status may also proxy for ability to pay. Several studies indicate that compliance is higher among employed noncustodial parents (Nichols-Casebolt and Danziger 1989; Peters et al. 1993) and those with higher educations (Peters et al. 1993). Remarriage of the noncustodial parent may reflect lower ability to pay, if such parents have additional dependents to support, although researchers have generally found either no effect on compliance (Peters et al. 1993) or higher compliance (Sonenstein and Calhoun 1990).

Researchers have also examined whether willingness to pay affects compliance. As noted above, willingness may be related to the economic need of the custodial-parent family as well as the strength of family ties between the noncustodial parent and his or her ex-partner and child(ren). The evidence here is mixed. Research does suggest that compliance varies with the strength of family ties, as proxied by contact between the noncustodial parent and children (Sonenstein and Calhoun 1990) and recent divorce (Garfinkel and Robins 1993). On the other hand, researchers have not found a direct link between joint legal custody and compliance (Seltzer 1991; Sonenstein and Calhoun 1990; 
Peters et al. 1993). There is no consistent evidence that compliance is higher when custodial parents have greater needs.

A substantial body of research suggests that the use of specific enforcement techniques, primarily the routine withholding of child support from income, is associated with increased compliance. Garfinkel and Klawitter (1990) estimated that immediate income withholding increases the compliance rate by 11 to 30 percent. Meyer and Bartfeld (1992a) found that the effect of routine withholding decreases over time, and speculate that this may be due to an inability of withholding orders to track employment changes. In a recent study exploiting interstate differences in child support policies, Garfinkel and Robins (1993) identified several state-level policy variables, including immediate withholding, advertisement of child support services, collection of support through a public agency, and higher child support expenditures, that have a positive impact on compliance. Using a similar approach, Beller and Graham (1993) found beneficial effects of policies including immediate withholding, criminal penalties, tax intercepts, and ability to place liens against property.

The relation between support guidelines and compliance has received considerably less attention in the literature; the bulk of the research on guidelines is limited to its implications for support orders, with the implicit assumption that similar impacts on payments would follow. However, Beller and Graham (1993) found that while use of guidelines increase the percentage of women who receive something, guidelines are associated with lower total payments. In our earlier work on compliance in nonmarital cases (Bartfeld and Meyer 1994), we found that compliance was lower for orders exceeding 15-20 percent of income-the percentage specified for one child in most current guidelines - than for orders in the 15-20 percent range. However, most noncustodial parents ordered to pay 15-20 percent of their income in support had just as high a compliance rate as parents ordered to pay a lower percentage of their income in support. An exception was found among the lowest-income parents, for whom low relative orders were associated with increased compliance. 
These findings suggest that the use of existing support guidelines in paternity cases is not likely to

have a detrimental affect on compliance, except in the case of the lowest-income parents.

In this paper, we move beyond prior work in four main ways:

1) We expand upon our previous research by examining the impact of the award relative to noncustodial income (the "burden" of the award) on compliance in divorce cases. Further, guidelines which seek to equalize well-being between custodial and noncustodial families, which have been discussed in principle but have not been implemented anywhere, would yield orders considerably higher than under any current guidelines. The relationship between compliance and the percentage of income owed in support can thus inform the debate about the likely effects of current and potential child support guidelines.

2) We provide additional information on the impact of routine income withholding on compliance by exploring differential effects of income withholding for noncustodial parents with different income sources.

3) We use a more accurate and timely measure of noncustodial-parent income than has typically been available for divorce cases. Understanding the relation between noncustodial income and compliance is particularly relevant in light of the increasing interest in enhancing noncustodial parents' earnings as a means of increasing child support.

4) Much previous research on compliance has either focused solely on divorce cases or incorporated divorce and paternity cases together without an explicit comparison. We go beyond the previous research by explicitly examining whether the characteristics of divorced fathers who do not comply with their child support orders differ from those of noncomplying paternity fathers. Understanding the way noncomplying divorce and nonmarital parents differ can contribute to optimal policy development for the two groups.

\section{DATA, VARIABLES, AND METHODS}

$\underline{\text { Data }}$

The primary data set used in this analysis is the Wisconsin Court Record Database (WCRD), collected and maintained by the Institute for Research on Poverty. This database consists of court record and payment history information on a sample of divorce, separation, and paternity cases involving at least one child under age eighteen from twenty-one Wisconsin counties. (For detailed discussion of the data and sampling procedures, see Brown et al., 1994). We examine cases that entered the courts between July 1980 and June 1988. There are data on payments and all support- 
related court actions for up to five years, as well as on case characteristics, support orders, and characteristics of both parents.

We also use a database containing income information from the Wisconsin Department of Revenue (DOR). Personal taxable income information, as well as marital status, is available annually, from 1980 through 1989, for parents in the WCRD who filed Wisconsin income tax returns. In any given year, tax data are missing for a subset of the parents - those who have moved out of state, those who are avoiding paying income taxes, and those with incomes too low to necessitate filing a return. Because Wisconsin offers a refundable tax credit to low-income people who rent their homes, many low-income people who are not obligated to file tax returns do so.

In this analysis, we select a subset of cases from the WCRD. Our sample includes divorce cases in which a child support order was in effect for the entire calendar year following the year of the first order, the father is the designated payer, and the mother has sole physical custody. We have excluded cases in which the amount of support owed or paid could not be determined from the data. We have limited the sample to cases in which the father is the payer and the mother has sole physical custody because these are the most common kinds of cases, and because the determinants of compliance may differ in other kinds of cases. The sample contains 3523 cases, with order dates ranging from 1980 to 1988. All dollar amounts have been adjusted to 1988 dollars, using the Consumer Price Index.

\section{$\underline{\text { Variables }}$}

The focus of this analysis is the relationship between compliance and three types of variables: those reflecting ability to pay, those reflecting child support enforcement efforts, and those which may proxy for the strength of family ties between the noncustodial parent and his ex-spouse and child(ren). The dependent variable, compliance, is defined as the ratio of support paid to support owed, measured 
in the calendar year following the year in which child support was first ordered. The compliance rate is coded as 1 when payments exceed obligations and is thus limited to a range of 0 to 1 .

As in our analysis of compliance in paternity cases (Bartfeld and Meyer 1994), we use two measures of ability to pay—total income and the percentage of current income owed in child support. We refer to the latter as the "burden" of the order. Note that these variables measure actual rather than potential ability to pay; we were unable to estimate the latter because the data do not contain enough information on items related to human capital.

We use two variables to capture the stringency of the child support enforcement system: the year in which compliance is measured, and the use of immediate income withholding. The year ranges from 1981 to 1989 , a period during which the emphasis on child support enforcement increased dramatically, both at the state and federal levels. Several important pieces of legislation relevant to child support enforcement were passed during this time. For instance, in 1981 Congress passed legislation providing for the interception of federal tax refunds to collect child support arrears, and the 1984 Child Support Amendments included a number of provisions aimed at increasing compliance. Thus, the year variable at least in part reflects the stringency of the enforcement system. The year variable could also reflect factors such as changing caseloads and changes in the economy which, if not adequately controlled, would confound its interpretation. We attempt to control for such factors in our analysis.

The second enforcement variable is the use of immediate income withholding, which refers to the withholding of child support obligations from the noncustodial parent's income from the time of the initial support order. Immediate withholding was first introduced in Wisconsin in 1984 on a pilot basis, and has been mandatory statewide since September 1987. A recent analysis indicates that immediate withholding was used even before such use was mandated, but it is still not used universally (Meyer et al. 1994). Use is most common when the parents have been married for a 
relatively short time and when the noncustodial parent's primary source of income is an employer, although there remains considerable variation across counties after controlling for these and other factors (Meyer and Bartfeld 1992b).

We define use of immediate withholding at the case level, and control for factors which have been shown to be correlated with its use. We also allow the impact of withholding to vary according to the payer's primary income source at the time the order was established, estimating separate effects for employed fathers, self-employed fathers, and fathers with no income or income from other miscellaneous sources such as Unemployment Compensation or other transfer programs. This is preferable to estimating a single withholding coefficient because the gains to immediate withholding may differ for different income sources.

Finally, we also include several variables which may proxy for the strength of family ties: the length of marriage, the age of the oldest child, the number of children, legal custody, and the remarriage of both parents. Due to data limitations, we are not able to include a measure of the extent of postdivorce contact between noncustodial parents and children.

Descriptive information about the variables we use is found in the Appendix.

$\underline{\text { Methods }}$

We use three strategies in our analysis. First, we present cross-tabulations showing the compliance rates according to variables related to ability to pay, the strength of ties, and the stringency of the enforcement system. In order to control for the relationship among these variables, we then use a multivariate approach, using maximum likelihood estimation to estimate a two-sided tobit model (Maddala 1983) in which

$$
Y^{*}=\beta_{1} X_{1}+\beta_{2} X_{2}+\beta_{3} X_{3}+\beta_{4} X_{4}+\beta_{5} C+\varepsilon
$$


and $\mathrm{Y}=$

0 if $\mathrm{Y}^{*} \leq 0$

$$
\begin{aligned}
& \mathrm{Y}^{*} \text { if } 0<\mathrm{Y}^{*}<1 \\
& 1 \text { if } \mathrm{Y}^{*} \geq 1
\end{aligned}
$$

where

$\mathrm{Y}=$ the ratio of child support paid to owed;

$\mathrm{Y}^{*}=$ an unobserved variable underlying $\mathrm{Y}$;

$\mathrm{X}_{1}=$ variables representing categories of father's income;

$\mathrm{X}_{2}=$ variables representing "burden" (the ratio of the order to the noncustodial parent's income);

$\mathrm{X}_{3}=$ variables representing the strength of the enforcement system, with variables representing the year in which compliance is measured and variables denoting cases with immediate withholding with different sources of income;

$\mathrm{X}_{4}=$ variables which proxy for the strength of family ties, including the length of marriage, the age of the oldest child, the number of children, legal custody, and whether the custodial or noncustodial parent remarried;

$\mathrm{C}=\mathrm{a}$ vector of control variables.

The control variables include indicator variables for counties, the income of the custodial parent, a variable that indicates cases in which the order is explicitly indexed to the payer's income, and variables indicating the source of the noncustodial parent's income. We include the county variables because child support orders are established, monitored, and enforced at the county level; compliance rates may therefore vary substantially among counties even after controlling for case-level characteristics. We include the other case-level variables because previous research has indicated that they may affect compliance, and because there may be caseload changes over the nine-year period which could confound our interpretation of the year variables. We have not included economic indicators such as county unemployment rate, because we assume that any effect of economic performance on compliance would operate through an effect on income. 
Finally, we take a closer look at fathers who are not complying with child support awards, examining their income, the level of their award compared to their income, and whether immediate income withholding was used. In this section, we compare divorced fathers with fathers from paternity cases.

There are limitations to our approach. In the multivariate analysis, we lack some potentially important information. Education and race are not available; although we control for any indirect effects they may have through income, we cannot control for any direct effects on compliance. Further, our variables for "family ties" are quite crude; in particular, we lack information on postdivorce contact between noncustodial parents and their children. Finally, data from Wisconsin may not be easily generalizable to the nation as a whole. We use data from Wisconsin because no national data provide information on noncustodial parents, custodial parents, and their children.

\section{RESULTS}

\section{Descriptive Results}

We begin by presenting descriptive data on compliance patterns in the sample as a whole as well as in various subgroups (Table 1). We present two types of information: the mean compliance rate (column 2), and the percentage of cases in each of three compliance categories-zero compliance, partial compliance, and full compliance, with the latter defined as paying at least 95 percent of the obligation (columns 3-5).

The compliance rate for the sample is .67, with 14 percent of fathers paying no support, 42 percent paying part of their obligation, and 44 percent paying in full. These percentages can be compared to those for a national sample of divorced mothers with children (not just recent divorces) in the 1990 Current Population Survey-Child Support Supplement. In the national sample, 23 percent received nothing, 20 percent received partial amounts, and 57 percent received the full amount. 
TABLE 1

Compliance with Child Support Awards

\begin{tabular}{|c|c|c|c|c|c|}
\hline & \multirow[b]{2}{*}{$\mathrm{N}$} & \multirow{2}{*}{$\begin{array}{c}\text { Mean } \\
\text { Compliance Rate }\end{array}$} & \multicolumn{3}{|c|}{ Percentage of Fathers Who: } \\
\hline & & & Pay Nothing & Pay in Part & Pay in Full \\
\hline Total & 3523 & .67 & 14 & 42 & 44 \\
\hline \multicolumn{6}{|l|}{ Father's income } \\
\hline Missing & 1243 & .50 & 26 & 47 & 28 \\
\hline$\leq \$ 10,000$ & 371 & .50 & 16 & 62 & 22 \\
\hline$\$ 10,001-\$ 20,000$ & 617 & .76 & 7 & 47 & 46 \\
\hline$\$ 20,001-\$ 30,000$ & 721 & .85 & 5 & 31 & 64 \\
\hline$\$ 30,001-\$ 40,000$ & 364 & .84 & 8 & 26 & 66 \\
\hline$>\$ 40,000$ & 207 & .77 & 13 & 24 & 63 \\
\hline \multicolumn{6}{|c|}{ Percentage of income owed } \\
\hline Missing & 1243 & .50 & & & \\
\hline$<10 \%$ & 351 & .78 & 11 & 28 & 61 \\
\hline $10-15 \%$ & 501 & .83 & 7 & 34 & 59 \\
\hline $16-20 \%$ & 454 & .82 & 7 & 34 & 59 \\
\hline $21-25 \%$ & 341 & .78 & 5 & 42 & 53 \\
\hline $26-30 \%$ & 173 & .78 & 6 & 46 & 49 \\
\hline $31-35 \%$ & 109 & .75 & 6 & 39 & 54 \\
\hline $36-50 \%$ & 151 & .63 & 10 & 53 & 37 \\
\hline $51-75 \%$ & 84 & .53 & 18 & 54 & 29 \\
\hline$>75 \%$ & 116 & .45 & 19 & 63 & 18 \\
\hline \multicolumn{6}{|l|}{ Year } \\
\hline 1981 & 158 & .54 & 18 & 56 & 26 \\
\hline 1982 & 572 & .63 & 17 & 45 & 38 \\
\hline 1983 & 600 & .61 & 19 & 44 & 37 \\
\hline 1985 & 474 & .64 & 15 & 46 & 39 \\
\hline 1986 & 575 & .71 & 13 & 38 & 50 \\
\hline 1987 & 679 & .72 & 11 & 40 & 49 \\
\hline 1988-1989 & 465 & .75 & 11 & 33 & 55 \\
\hline \multicolumn{6}{|c|}{ Use of immediate withholding } \\
\hline Yes & 1537 & .75 & 9 & 39 & 52 \\
\hline No & 1986 & .61 & 19 & 44 & 38 \\
\hline
\end{tabular}


TABLE 1, continued

\begin{tabular}{|c|c|c|c|c|c|}
\hline & \multirow[b]{2}{*}{$\mathrm{N}$} & \multirow{2}{*}{$\begin{array}{c}\text { Mean } \\
\text { Compliance Rate }\end{array}$} & \multicolumn{3}{|c|}{ Percentage of Fathers Who: } \\
\hline & & & Pay Nothing & Pay in Part & Pay in Full \\
\hline \multicolumn{6}{|l|}{ Length of marriage } \\
\hline Missing & 36 & .75 & (3) & (49) & (49) \\
\hline$<2$ years & 158 & .58 & 18 & 52 & 30 \\
\hline $2-5$ years & 682 & .61 & 14 & 51 & 35 \\
\hline $6-9$ years & 1129 & .68 & 14 & 43 & 44 \\
\hline$\geq 10$ years & 1518 & .70 & 15 & 36 & 49 \\
\hline \multicolumn{6}{|l|}{ Age of oldest child } \\
\hline Missing & 43 & .65 & 14 & 40 & 47 \\
\hline$<2$ & 408 & .60 & 16 & 50 & 34 \\
\hline $2-4$ & 869 & .64 & 14 & 45 & 41 \\
\hline $5-9$ & 1039 & .68 & 14 & 41 & 45 \\
\hline $10-12$ & 406 & .72 & 13 & 36 & 51 \\
\hline$\geq 13$ & 758 & .69 & 16 & 37 & 47 \\
\hline \multicolumn{6}{|l|}{ Number of children } \\
\hline 1 & 1486 & .66 & 15 & 43 & 42 \\
\hline 2 & 1450 & .68 & 14 & 40 & 46 \\
\hline $3+$ & 585 & .66 & 15 & 41 & 44 \\
\hline \multicolumn{6}{|l|}{ Legal custody } \\
\hline Missing & 79 & .66 & 9 & 58 & 33 \\
\hline Mother has custody & 2607 & .64 & 16 & 44 & 40 \\
\hline Joint/Split & 837 & .75 & 11 & 33 & 56 \\
\hline \multicolumn{6}{|l|}{ Custodial remarriage } \\
\hline Missing & 1736 & .63 & 16 & 45 & 39 \\
\hline No & 1714 & .71 & 13 & 38 & 49 \\
\hline Yes & 73 & .67 & 11 & 51 & 38 \\
\hline \multicolumn{6}{|c|}{ Noncustodial remarriage } \\
\hline Missing & 1271 & .50 & 26 & 46 & 28 \\
\hline No & 1988 & .76 & 8 & 39 & 53 \\
\hline Yes & 264 & .77 & 10 & 36 & 55 \\
\hline
\end{tabular}


As shown in the table, the compliance rate varies substantially according to all of the abilityto-pay and enforcement variables, and some of the variables that reflect family ties. As expected, compliance increases dramatically with income, although it does fall somewhat for the highest-income payers. Compliance rates increase from .50 for fathers earning no more than $\$ 10,000$ to .84 for those earning $\$ 30,001-\$ 40,000$, with the share of nonpayers falling from 16 percent to 8 percent and full payers increasing from 22 percent to 66 percent. Note, though, that in the highest income category mean compliance falls to .77 , and nonpayers increase to 13 percent.

Compliance also varies with the relative burden of support orders. The pay-to-owe ratio decreases as the percentage of income owed in support increases (with the exception of the lowestorder category). The highest compliance rate (.83) is for those owing 10-15 percent of current income, while the lowest rate (.45) is for those owing more than 75 percent of current income. Over this range, nonpayers increase from 7 percent to 19 percent, while full payers fall from 59 percent to 18 percent.

The enforcement variables also appear important. Compliance increases substantially over time, from .54 in 1981 to .75 in $1988-1989$, with most of the change occurring by 1986 . The percentage of fathers paying in full more than doubles over this period, from 26 percent to 55 percent, and the percentage who pay nothing declines from 18 percent to 11 percent. The compliance rate for cases without immediate withholding is .61 , compared to .75 for cases in which immediate withholding is used. Cases without immediate withholding are more than twice as likely to be nonpayers (19 percent versus 9 percent), and correspondingly less likely to be full payers (38 percent versus 52 percent).

Compliance varies to some extent with the length of the marriage and the age of the oldest child. Compliance increases from .58 for the shortest marriages to .70 for the longest, and from .60 for cases in which the oldest child is under two to .69 for cases with teenagers. Compliance rates are 
quite similar for families with differing numbers of children. In cases in which the parents have joint or split legal custody, compliance is higher than cases with sole mother custody (.75 vs .64).

Because of interrelationships among the above variables, we cannot sort out their true effects without a multivariate approach. For instance, high orders relative to income are found disproportionately among the lowest-income fathers; immediate withholding is used far more frequently in cases decided in the late 1980s; and parents who were married longer tend to have older children and higher incomes. To discern the independent role of the various variables, we estimate a double-sided tobit model with compliance as the dependent variable, as described earlier.

\section{$\underline{\text { Multivariate Results }}$}

The results of the tobit model are reported in Table 2 and generally support the bivariate results discussed above. Lower incomes are associated with lower compliance rates; the decrease in compliance at higher incomes is not statistically significant.

The burden of the order is also important, although only at higher levels. The coefficients for the two lower-order categories (less than 10 percent and 10-15 percent) are not significantly different from zero, nor are the coefficients for orders from 21-25 percent and 26-30 percent of income (the omitted category is $16-20$ percent), although the latter is negative and approaches significance. The coefficients for order categories over 30 percent are negative and significantly different from zero, and increase in magnitude. These results suggest that up to around 25 percent of income, the relative burden of support orders is not associated with differential compliance rates. The 26-30 percent range appears to be a turning point after which compliance steadily falls. We also estimated a model in which the percentage variables were interacted with number of children (not shown). The interaction variables were not significant either separately or as a block; thus we found no evidence that the relationship between the relative order and compliance varies with the number of children. 
TABLE 2

Compliance with Child Support Awards: Multivariate Results

\begin{tabular}{|c|c|c|}
\hline & Coefficient & Std. Error \\
\hline \multicolumn{3}{|c|}{ Father's income (compared to $\$ 20,001-\$ 30,000$ ) } \\
\hline$\$ 0-\$ 10,000$ & $-0.389 * * *$ & 0.048 \\
\hline$\$ 10,001-\$ 20,000$ & $-0.166^{* * *}$ & 0.036 \\
\hline$\$ 30,001-\$ 40,000$ & -0.018 & 0.043 \\
\hline$>\$ 40,000$ & -0.071 & 0.054 \\
\hline Missing & $-0.238^{*}$ & 0.125 \\
\hline \multicolumn{3}{|c|}{ Percentage of income owed (compared to $16-20 \%$ ) } \\
\hline$<10 \%$ & -0.008 & 0.049 \\
\hline $10-15 \%$ & 0.009 & 0.042 \\
\hline $21-25 \%$ & -0.038 & 0.046 \\
\hline $26-30 \%$ & -0.083 & 0.054 \\
\hline $31-35 \%$ & $-0.129 * *$ & 0.065 \\
\hline $36-50 \%$ & $-0.171 * * *$ & 0.059 \\
\hline $51-75 \%$ & $-0.226^{* * *}$ & 0.077 \\
\hline$>75 \%$ & $-0.232 * * *$ & 0.080 \\
\hline \multicolumn{3}{|l|}{ Year (compared to 1981$)$} \\
\hline 1982 & $0.175^{* * *}$ & 0.056 \\
\hline 1983 & $0.133 * *$ & 0.056 \\
\hline 1985 & $0.200 * * *$ & 0.059 \\
\hline 1986 & $0.241 * * *$ & 0.059 \\
\hline 1987 & $0.245 * * *$ & 0.058 \\
\hline 1988-1989 & $0.305 * * *$ & 0.062 \\
\hline Immediate withholding-employment & $0.119 * * *$ & 0.031 \\
\hline Immediate withholding - self-employed & 0.120 & 0.100 \\
\hline Immediate withholding-miscellaneous & 0.053 & 0.050 \\
\hline Years married & 0.004 & 0.003 \\
\hline \multicolumn{3}{|l|}{ Oldest child's age (compared to age 11-18) } \\
\hline $0-2$ & 0.061 & 0.053 \\
\hline $3-5$ & 0.028 & 0.045 \\
\hline $6-10$ & 0.048 & 0.036 \\
\hline Two children & 0.005 & 0.025 \\
\hline Three or more children & 0.008 & 0.037 \\
\hline
\end{tabular}

(table continues) 
TABLE 2, continued

\begin{tabular}{llc}
\hline & Coefficient & Std. Error \\
\hline Joint legal custody & 0.042 & 0.027 \\
Mother not remarried & -0.018 & 0.077 \\
Mother's marital status missing & 0.003 & 0.158 \\
Father not remarried & 0.033 & 0.043 \\
Father's marital status missing & $-0.314^{* *}$ & 0.127 \\
& & 0.098 \\
Percentage-expressed order & -0.158 & 0.001 \\
Mother's income & & 0.140 \\
Mother's income missing & $0.003^{*}$ & \\
& -0.000 & 0.086 \\
Father's income source (compared to no source) & & 0.095 \\
Job & $0.407^{* * *}$ & 0.109 \\
Self-employment & $0.406^{* * *}$ & 0.125 \\
Unemployment & $0.333^{* * *}$ & 0.086 \\
Miscellaneous & $0.278^{* *}$ & \\
Missing & $0.320^{* * *}$ & 0.148 \\
Intercept & $0.253^{*}$ & \\
N=3514 & & \\
Log-likelihood: -3013 & & \\
\hline
\end{tabular}

Notes: Not shown here are dummy variables for counties and missing marriage length, child's age, and legal custody; the coefficients on these variables are available from the authors on request.

*** Significantly different from zero, .01 level.

** Significantly different from zero, .05 level.

* Significantly different from zero, .10 level. 
The coefficients on the variables reflecting the enforcement system support the hypothesis that stronger enforcement is associated with higher compliance. The coefficients on all the year variables are significantly different from zero (1981 is the omitted category) and are largest for the latest years. All three withholding variables are positive, but only the coefficient for immediate withholding from employed parents is significantly different from zero. Thus, the model provides no convincing evidence that immediately withholding payments from the incomes of fathers who are selfemployed or non-employed is associated with increased compliance in the short term, although the signs of the coefficients are in the expected direction.

Finally, none of the variables proxying for family ties show significant effects. Included here are marriage length, age of oldest child, number of children, legal custody, and custodial and noncustodial remarriage. Because of the high correlation between marriage length and child's age, we reestimated the model using only one of these variables at a time (not shown); in neither model were the variables significant.

In Table 3, we present predicted compliance rates for a variety of prototypical cases that differ in income level, percentage of income owed, use of immediate withholding, and year. For all cases, we assume there is one child and that employment is the payer's primary income source; the remaining variables are set at the mean.

As the earlier discussion suggests, the predicted compliance rate varies substantially with the father's ability to pay and the stringency of the enforcement system. The lowest predicted compliance rate shown, .41 , is for a case in 1981 in which the father earns no more than $\$ 10,000$, owes $15-20$ percent of his income in child support, and does not have an immediate withholding order (Case A). For an analogous case in 1988 (Case B), the predicted compliance rate is .60.

Predicted compliance also varies dramatically with income, especially in the lower income categories. The predicted compliance rate for the above case increases from .60 to .72 with an income 
TABLE 3

Predicted Compliance for Prototypical Cases, Based on Tobit Model

\begin{tabular}{llcccc}
\hline Case & Income & $\begin{array}{c}\text { Percentage } \\
\text { Owed }\end{array}$ & $\begin{array}{c}\text { Immediate } \\
\text { Withholding }\end{array}$ & Year & $\begin{array}{c}\text { Predicted } \\
\text { Compliance }\end{array}$ \\
\hline A & $\leq \$ 10,000$ & $15-20 \%$ & No & 1981 & .41 \\
B & $\leq \$ 10,000$ & $15-20 \%$ & No & 1988 & .60 \\
C & $\$ 10,001-\$ 20,000$ & $15-20 \%$ & No & 1988 & .72 \\
D & $\$ 10,001-\$ 20,000$ & $15-20 \%$ & Yes & 1988 & .78 \\
E & $\$ 20,001-\$ 30,000$ & $15-20 \%$ & Yes & 1988 & .85 \\
F & $\$ 20,001-\$ 30,000$ & $30-35 \%$ & Yes & 1988 & .80 \\
G & $\$ 20,001-\$ 30,000$ & $35-50 \%$ & Yes & 1988 & .78 \\
H & $\$ 20,001-\$ 30,000$ & $50-75 \%$ & Yes & 1988 & .75 \\
I & $\$ 30,001-\$ 40,000$ & $15-20 \%$ & Yes & 1988 & .84 \\
J & $>\$ 40,000$ & $15-20 \%$ & Yes & 1988 & .82 \\
\hline
\end{tabular}


of $\$ 10,001-\$ 20,000$ (Case C) instead of $\$ 10,000$ or less; adding immediate withholding increases the predicted rate to .78 (Case D).

Further increases in income have less of an impact and eventually yield lower predicted compliance, although the drop is not significant. Keeping withholding and increasing income to $\$ 20,001-\$ 30,000$ yields a predicted rate of .85 (Case E); an analogous case with an income of $\$ 30,001-\$ 40,000$ (Case I) has a similar rate (.84); and increasing the income to above $\$ 40,000$ yields a slightly lower rate of .82 (Case J).

Finally, the burden of the support order is also important. Returning to a case in the $\$ 20,001-\$ 30,000$ range, predicted compliance falls steadily as more of that income is owed in support: the predicted rates are .85 for orders of $15-20$ percent (Case E), .80 for orders of 30-35 percent (Case F), .78 for orders of $35-50$ percent (Case G), and .75 for orders of 50-75 percent (Case H). Note that the effect of relative orders, while definitely present, is not pronounced: the difference in predicted compliance between a parent who owes 15-20 percent and one who owes 50-75 percent is only ten percentage points; for all orders below 30 percent, a range which includes most guidelines currently in use, the predicted compliance rates only vary minimally.

\section{Who Are Noncompliers?}

The previous analysis shed some light on the determinants of compliance in divorce cases, and confirmed the importance of enforcement and ability to pay. The findings are consistent with recent work on compliance in paternity cases. In this section, we take a closer look at noncompliers in paternity and divorce cases (both nonpayers and partial payers), presenting distributional information on income, percentage of income owed in support, and use of immediate withholding.

The first panel in Table 4 shows the income distribution of nonpayers and partial payers in divorce and paternity cases. Note that income information is missing for a substantial share of cases, especially the nonpayers, precluding definitive conclusions. However, of cases with income 
information, the differences between divorce and paternity cases are striking. Noncomplying fathers in paternity cases have considerably lower incomes than do noncomplying divorced fathers. While 31 percent of nonpaying fathers in divorce cases have incomes at or below $\$ 10,000$, two-thirds of nonpaying fathers in nonmarital cases have incomes in this range. Conversely, half of the nonpaying divorced fathers have incomes above $\$ 20,000$, compared to only 10 percent of nonpaying nonmarital fathers. For the partial payers, nonmarital fathers are again much worse off than divorced fathers. These results suggest that, while low ability to pay may play a substantial role in contributing to noncompliance in paternity cases, its role in divorce cases is considerably less important. While $\$ 20,000$ is not necessarily a high income, it seems unlikely that fathers earning above this amount—half of all nonpaying divorced fathers in this sample—cannot afford to pay at least something. On the other hand, note that one-third of nonpaying and one-quarter of partial paying divorced fathers do have extremely low incomes.

To what extent might the missing income information bias these results? We have some information in the court record about income in the year the case came to court. Such information is available for roughly half of divorced fathers and one-quarter of nonmarital fathers for whom income is not available in the tax records. Cases with income information in the court record but not the tax record tend to show slightly lower incomes for nonpayers and similar incomes for partial payers. In all cases, nonpaying and partial paying divorced fathers have substantially higher mean incomes than nonmarital fathers.

The second panel in Table 4 shows the distribution of support orders relative to income. For the nonpayers, divorced and nonmarital fathers are not significantly different, with orders ranging from below 10 percent to above 75 percent of current income, though more concentrated in the lower end. For the partial payers, fathers in nonmarital cases have lower relative orders than do fathers in divorce cases. Note that the sample includes cases which entered the courts as early as 1980, when 
TABLE 4

Characteristics of Noncompliers in Divorce and Paternity Cases

\begin{tabular}{lccccc}
\hline & \multicolumn{2}{c}{ Nonpayers } & & \multicolumn{2}{c}{ Partial Payers } \\
& Divorce & Paternity & & Divorce & Paternity \\
\hline Of those with known fathers' income: ${ }^{\mathrm{a}, \mathrm{b}}$ & & & & & \\
Income $\leq \$ 10,000$ & $31 \%$ & $67 \%$ & & $26 \%$ & $55 \%$ \\
Income $\$ 10,001-\$ 20,000$ & $23 \%$ & $22 \%$ & & $33 \%$ & $32 \%$ \\
Income $\$ 20,001-\$ 30,000$ & $19 \%$ & $7 \%$ & & $25 \%$ & $10 \%$ \\
Income $\$ 30,001-\$ 40,000$ & $15 \%$ & $3 \%$ & & $11 \%$ & $3 \%$ \\
Income $>\$ 40,000$ & $14 \%$ & $0 \%$ & & $6 \%$ & $0 \%$ \\
$\mathrm{~N}$ & 193 & 107 & & 887 & 358
\end{tabular}

Percentage of cases with missing income: Divorce nonpayers, 61\%; paternity nonpayers, 74\%; divorce partial payers, $39 \%$; paternity partial payers, $44 \%$.

Of those with known percent owed in support: ${ }^{\mathrm{b}}$

$\begin{array}{lrrrr}\text { Owe }<10 \% & 20 \% & 25 \% & 11 \% & 37 \% \\ \text { Owe 10-15\% } & 18 \% & 16 \% & 19 \% & 22 \% \\ \text { Owe 16-20\% } & 17 \% & 6 \% & 18 \% & 12 \% \\ \text { Owe 21-25\% } & 9 \% & 9 \% & 16 \% & 8 \% \\ \text { Owe 26-30\% } & 5 \% & 10 \% & 9 \% & 5 \% \\ \text { Owe 31-35\% } & 4 \% & 3 \% & 5 \% & 3 \% \\ \text { Owe 36-50\% } & 8 \% & 10 \% & 9 \% & 5 \% \\ \text { Owe 51-75\% } & 8 \% & 8 \% & 5 \% & 5 \% \\ \text { Owe }>75 \% & 11 \% & 15 \% & 8 \% & 4 \% \\ \mathrm{~N} & 193 & 105 & 887 & 347\end{array}$

Percentage of cases with missing income: Divorce nonpayers, 62\%; paternity nonpayers, 73\%; divorce partial payers, $40 \%$; paternity partial payers, $43 \%$.

Immediate withholding order among cases from 1987-1989:

\begin{tabular}{lrrrr} 
Yes & $53 \%$ & $73 \%$ & $76 \%$ & $91 \%$ \\
No & $47 \%$ & $27 \%$ & $24 \%$ & $9 \%$ \\
Employed & $17 \%$ & $6 \%$ & $12 \%$ & $4 \%$ \\
Self-employed & $5 \%$ & $4 \%$ & $5 \%$ & $2 \%$ \\
Other/Missing & $24 \%$ & $17 \%$ & $6 \%$ & $3 \%$ \\
N & 62 & 52 & 216 & 139 \\
\hline
\end{tabular}

${ }^{a}$ The distribution of divorced nonpayers differs from the distribution of paternity nonpayers according to a $\chi^{2}$ test $(\mathrm{p}<.05)$.

${ }^{b}$ The distribution of divorced partial payers differs from the distribution of paternity partial payers according to a $\chi^{2}$ test $(\mathrm{p}<.05)$. 
support guidelines were not in effect. Note also that the cases in the paternity sample all involve one child, while the divorce cases may involve several children.

Finally, the last panel shows the breakdown of noncompliers according to whether a routine withholding order was issued. Here, we only include the subsample of cases in the most recent cohorts, which were subject to routine withholding requirements. Among both categories of noncompliers, withholding orders are more common in paternity cases than divorce cases ( 73 percent vs. 53 percent for nonpayers, and 91 percent vs. 76 percent for partial payers), implying that more thorough implementation of immediate withholding requirements has greater potential to increase compliance in divorce cases than in nonmarital cases. Still, most of the noncomplying fathers-paternity or divorce, nonpayer or partial payer-already have a withholding order, and most of those without such an order receive their income primarily from sources other than outside employment. This suggests that most of the likely gains from immediate withholding, at least as it is currently implemented, have already been realized. Of course, if withholding were not so widely used, the remaining noncompliance problem would be much more extensive.

\section{V. $\quad$ CONCLUSIONS AND POLICY IMPLICATIONS}

These results indicate that enforcement has had a large, beneficial impact on compliance with child support orders. Controlling for various case characteristics, compliance increased dramatically over the 1980s, an effect which can likely be attributed at least in part to the greater emphasis on enforcement over this period. Immediate withholding, a specific enforcement strategy phased in between 1984 and 1987, is associated with significantly higher compliance rates among those payers for whom employment is their primary income source; the effect of withholding is not significant for payers with other income sources. 
Further, these results suggest that greater ability to pay is associated with higher compliance rates. Compliance generally increases with income, although it does fall in the highest income range; the "burden" of awards is not related to compliance until more than 30 percent of income is owed, an effect that holds regardless of the number of children.

We found no evidence that strength of family ties is associated with the compliance rate. Note, however, that our family ties variables are crude and do not capture the extent of fathers' postdivorce interactions with their children.

These results can be contrasted with the findings of our previous research on compliance among paternity cases. Overall compliance among divorce cases is higher, with a mean compliance rate of .67 compared to $.48 ; 14$ percent of the divorced fathers pay nothing, compared to 29 percent of the paternity fathers. While we find a strong relationship between noncustodial income and compliance for both groups, low incomes are much more of a problem among noncomplying nonmarital fathers than among noncomplying divorced fathers: if we examine the fathers who were supposed to pay child support for whom we have income information, two-thirds of the nonpaying paternity fathers had incomes at or below $\$ 10,000$, compared to only one-third of the nonpaying divorced fathers. In both groups, fathers with orders in the range of typical support guidelines were just as likely to comply as those with very low orders (except for the poorest paternity fathers, for whom very low orders were associated with higher compliance). In both groups, compliance increased over the course of the 1980s, and immediate withholding increased compliance.

These results have several potential implications for public policy. As discussed earlier, policies aimed at promoting compliance have overwhelmingly emphasized enforcement. The increase in compliance over time, and the higher compliance in cases with immediate withholding orders, suggests that this strategy has indeed been effective. However, our results indicate that the bulk of the gains possible from immediate withholding, at least as currently carried out, may have already been 
realized in Wisconsin, since relatively few employed noncompliers lack withholding orders. Achieving further gains from immediate withholding may require shifting focus from simply issuing withholding orders to making withholding more effective, perhaps by improving the capacity of the courts to track job changes among those who owe support.

Our comparison of noncomplying divorced fathers with noncomplying paternity fathers suggests that the optimal policy response for the two groups may differ. In particular, programs designed to increase the earnings capacity of noncustodial fathers may be more important for fathers in paternity cases, while careful attention to enforcement may be more important for fathers in divorce cases.

Another policy implication follows from our findings on the relation between the order amount and the compliance rate. We find that orders between 0 percent and 30 percent of the noncustodial parent's income have similar compliance rates. Support guidelines up to the top of this range should not have a negative effect on compliance rates. While guidelines that require more than 30 percent of the noncustodial parent's income may still be considered, our results suggest that such orders may involve a tradeoff in the form of lower compliance. 
APPENDIX

\section{Information on Variables Used}

\begin{tabular}{|c|c|c|}
\hline & Mean & Std. Deviation \\
\hline \multicolumn{3}{|l|}{ Father's income } \\
\hline$\$ 0-\$ 10,000$ & 0.106 & 0.307 \\
\hline$\$ 10,001-\$ 20,000$ & 0.176 & 0.381 \\
\hline$\$ 20,001-\$ 30,000$ & 0.205 & 0.404 \\
\hline$\$ 30,001-\$ 40,000$ & 0.104 & 0.305 \\
\hline$>\$ 40,000$ & 0.059 & 0.235 \\
\hline Missing & 0.351 & 0.477 \\
\hline \multicolumn{3}{|l|}{ Percentage of income owed } \\
\hline $10 \%$ & 0.087 & 0.282 \\
\hline $10-15 \%$ & 0.139 & 0.346 \\
\hline $16-20 \%$ & 0.134 & 0.341 \\
\hline $21-25 \%$ & 0.097 & 0.296 \\
\hline $26-30 \%$ & 0.057 & 0.232 \\
\hline $31-35 \%$ & 0.033 & 0.179 \\
\hline $36-50 \%$ & 0.044 & 0.205 \\
\hline $51-75 \%$ & 0.024 & 0.154 \\
\hline $75 \%$ & 0.024 & 0.152 \\
\hline \multicolumn{3}{|l|}{ Year } \\
\hline 1981 & 0.045 & 0.207 \\
\hline 1982 & 0.163 & 0.370 \\
\hline 1983 & 0.171 & 0.377 \\
\hline 1985 & 0.135 & 0.341 \\
\hline 1986 & 0.163 & 0.370 \\
\hline 1987 & 0.193 & 0.394 \\
\hline 1988-1989 & 0.130 & 0.337 \\
\hline Immediate withholding_employment & 0.353 & 0.478 \\
\hline Immediate withholding — self-employed & 0.015 & 0.123 \\
\hline Immediate withholding - miscellaneous & 0.067 & 0.250 \\
\hline Years married & 9.492 & 6.364 \\
\hline Missing marriage length & 0.010 & 0.101 \\
\hline \multicolumn{3}{|l|}{ Oldest child's age } \\
\hline Missing & 0.012 & 0.110 \\
\hline $0-2$ & 0.200 & 0.400 \\
\hline $3-5$ & 0.230 & 0.420 \\
\hline $6-10$ & 0.269 & 0.443 \\
\hline$>10$ & 0.289 & 0.453 \\
\hline
\end{tabular}


26

APPENDIX, continued

\begin{tabular}{lcc}
\hline & Mean & Std. Deviation \\
\hline One child & 0.421 & 0.494 \\
Two children & 0.411 & 0.492 \\
Three or more children & 0.127 & 0.333 \\
& & \\
Missing legal custody & 0.003 & 0.053 \\
Joint legal custody & 0.238 & 0.426 \\
& & \\
Mother not remarried & 0.487 & 0.500 \\
Mother's marital status missing & 0.492 & 0.500 \\
Father not remarried & 0.566 & 0.496 \\
Father's marital status missing & 0.359 & 0.480 \\
& & 0.114 \\
Percentage-expressed order & 0.013 & 10.710 \\
& & 0.500 \\
Mother's income & 7.201 & \\
Mother's income missing & 0.486 & 0.473 \\
Father's income source & & 0.253 \\
$\quad$ Job & & 0.145 \\
$\quad$ Self-employment & 0.664 & 0.114 \\
$\quad$ Unemployment & 0.069 & 0.411 \\
$\quad$ Miscellaneous & 0.021 & \\
$\quad$ Missing & 0.013 & \\
\hline
\end{tabular}




\section{References}

Bartfeld, Judi and Daniel R. Meyer. 1994. "Are There Really Dead-Beat Dads? The Relationship between Enforcement, Ability to Pay, and Compliance in Nonmarital Child Support Cases." $\underline{\text { Social Service }}$ Review 68(2): 219-35.

Beller, Andrea H. and John W. Graham. 1993. Small Change: The Economics of Child Support. New Haven, Conn.: Yale University Press.

Brown, Pat, Carol L. Roan, and J. Laird Marshall. 1994. "Sample Design, Wisconsin Child Support Demonstration Project." Institute for Research on Poverty, University of Wisconsin-Madison, June 1994.

Danziger, Sandra K. and Ann Nichols-Casebolt. 1990. "Child Support in Paternity Cases." Social Service Review 64: 458-74.

Garfinkel, Irwin and Marieka M. Klawitter. 1990. "The Effect of Routine Income Withholding of Child Support Collections." Journal of Policy Analysis and Management 9: 155-77.

Garfinkel, Irwin, Sara S. McLanahan, and Philip K. Robins, eds. 1992. Child Support Assurance. Washington, D.C.: The Urban Institute Press.

Garfinkel, Irwin and Philip K. Robins. 1993. "The Relationship between Child Support Enforcement Tools and Child Support Outcomes." Discussion Paper no. 1004-93 (Institute for Research on Poverty, University of Wisconsin-Madison).

Gordon, Anne R. 1991. "Income Withholding, Medical Support and Services to Non-AFDC Cases after the Child Support Enforcement Amendments of 1984." Volume I. Princeton, N.J.: Mathematica Policy Research, Inc. Report submitted to the U.S. Office of Child Support Enforcement under contract 282-87-1009.

Maddala, G. S. 1983. Limited-Dependent and Qualitative Variables in Econometrics. Cambridge: Cambridge University Press. 
Meyer, Daniel R. and Judi Bartfeld. 1992a. "The Effects of the Immediate Withholding of Child Support on Collections over Time." Institute for Research on Poverty, University of Wisconsin-Madison: Final report to the Wisconsin Department of Health and Social Services, June 1992. 1992b. "How Routine is 'Routine' Withholding?" Institute for Research on Poverty, University of Wisconsin-Madison: Final report to the Wisconsin Department of Health and Social Services, June 1992.

Meyer, Daniel R., Irwin Garfinkel, Judi Bartfeld, and Pat Brown. 1994. "An Evolving Child Support System." Focus 16(1): 1-14.

Nichols-Casebolt, Ann and Sandra K. Danziger. 1989. "The Effect of Childbearing Age on Child Support Awards and Economic Well-Being among Divorcing Mothers." Journal of Divorce 12(4): 34-38.

O’Neill, June. 1985. "Determinants of Child Support." Final report prepared for the Demographic and Behavioral Sciences Branch, National Institute on Child Health and Human Development, under grant no. IR01HD 16840-01. Washington, D.C.: The Urban Institute.

Peters, H. Elizabeth, Laura M. Argys, Eleanor E. Maccoby, and Robert H. Mnookin. 1993. "Enforcing Divorce Settlements: Evidence from Child Support Compliance and Award Modifications." Demography 30: $719-35$.

Seltzer, Judith A. 1991. "Legal Custody Arrangements and Children's Economic Welfare." American Journal of Sociology 96: 895-929.

Sonenstein, Freya L. and Charles A. Calhoun. 1990. "Determinants of Child Support: A Pilot Survey of Absent Parents." Contemporary Policy Issues 8: 75-94.

U.S. Bureau of the Census. 1991. Current Population Reports, Series P-60, no. 173. Child Support and Alimony: 1989. Washington, D.C.: U.S. Government Printing Office. 